\title{
MAIN DEFECTS AND DETERIORATIONS OF REINFORCED CONCRETE STRUCTURES IN THE ABANDONED HYDRAULIC STRUCTURES OF LITHUANIA
}

\begin{abstract}
Raimondas ŠADZEVIČIUS, Institute of Hydraulic Engineering, Faculty of Water and Land Management, Vytautas Magnus University, K. Donelaičio g. 58, LT-44248 Kaunas, Lithuania, raimondas.sadzevicius@ vdu.lt (corresponding author)

Rytis SKOMINAS, Institute of Hydraulic Engineering, Faculty of Water and Land Management, Vytautas Magnus University, K. Donelaičio g. 58, LT-44248 Kaunas, Lithuania, rytis.skominas@ vdu.lt

Tatjana SANKAUSKIENÉ, Institute of Hydraulic Engineering, Faculty of Water and Land Management, Vytautas Magnus University, K. Donelaičio g. 58, LT-44248 Kaunas, Lithuania, tatjana.sankauskiene@ vdu.lt

Dainius RAMUKEVIČIUS, Institute of Hydraulic Engineering, Faculty of Water and Land Management, Vytautas Magnus University, K. Donelaičio g. 58, LT-44248 Kaunas, Lithuania, dainius.ramukevicius@ vdu.lt

Many abandoned (term "hostless" by 2010) hydraulic structures have been exploited for over 30 years, so due to the aging of materials, the probability of failures and accidents increases. Due to the insufficient exploitation in several dams the breakdowns occurred, some ponds in damaged dams have been emptied. It is known that no comprehensive research on technical state evaluation of abandoned hydraulic structures in Lithuania has been carried out. It becomes clear that practical, scientifically based algorithms for the technical state evaluation of abandoned hydraulic structures are needed in order to assess the impact of environmental factors on the technical state, safety, reliability and durability of structures. This paper focuses on the presentation of investigation results of technical state evaluation of 4 abandoned hydraulic structures with ponds in Raseiniai district. Due to the noticed significant defects and deteriorations all 4 abandoned hydraulic structures with ponds are in critical state, the pond in Gyliai IV is emptied, the demolition of reinforced concrete structures should be applied in this object.
\end{abstract}

Keywords: abandoned hydraulic structures, defects, deteriorations.

\section{INTRODUCTION}

From 1950 to 1990 a lot of middle and small dams were constructed for the purpose of antierosion, irrigation, energetics, recreation, fishing, etc. At present time in Lithuania there are about 1100 dams with the reservoir area larger than 0,5 hectares (Catalog of ponds, 1998).

In accordance with their importance to the reliability and strength of all the hydroscheme construction, hydraulic structures (Technical Construction Regulation STR 2.02.06:2004) may be divided into two categories: the main structures and the auxiliary ones. The below mentioned constructions of the hydrosheme belong to the category of the main structures: earth dam crest; upstream slope (with its berms and revetment); downstream slope (with its berms and revetment), earth dam foot; drainage (inner pipes drainage and wells, superficies on a slope, inner prismatic, drainage ditch); part of a surplus water fall spillway (drop inlet, siphon, bucket, rapids); gates; gate operating devices (for raising and lowering); conduit; downstream apron I with its mufflers. The below mentioned constructions of the hydrosheme, belong to the category of the auxiliary structures (less important dam elements): surface water collection flumes; small service bridge (for maintenance and exploiting); piers and small piers; downstream apron II; end lining; downstream channel. In the case of present concrete spillway dam, piers have to be attributed to the category of main structures of a hydroscheme (Damulevičius et al, 2001).

The technical state of dams in Lithuania has been periodically investigated by researchers from Lithuanian Academy of Agriculture. Using visual observations and field investigations over 110 earth dams (hereinafter $E D)$ have been investigated from 1997 to 1999. In 1997 (Lindišas et al. 1997) the technical state of 313 dams (owned by Reclamation Service) was evaluated as follows: good for 143 dams (38.9\%); satisfactory for 120 dams (32.6\%); unsatisfactory for 58 dams (15.8\%). Researches on the technical state of 260 Lithuanian earth dams were continued from 2002 to 2009. It was found that 15 earth dams (EDs) (6\%) are in good state, 109 EDs (42\%) are in moderate state, 87 EDs (34\%) are in satisfactory state, 22 EDs (8\%) are in unsatisfactory state, and 27 EDs $(10 \%)$ are in critical state. Comparing the ED state evaluation results, obtained in 1997 to those obtained from 2002 to 2009 it was found that ED technical state in Lithuania had worsened from 2002 to 2009. The investigations showed that the number of objects in unsatisfactory and critical state increased up to $19 \%$, when in 1997, 16\% of the total amount of investigated objects were in unsatisfactory state (Šadzevičius et al, 2013).

Copyright (C) 2019 The Authors. Published by Vytautas Magnus University. This is an open-access article distributed under the terms of the Creative Commons Attribution License (CC BY 4.0), which permits unrestricted use, distribution, and reproduction in any medium, provided the original author and source are credited. 
The analysis of the technical state changes of spillway concrete gravity dams in some municipalities of Lithuania were presented in literature (Šadzevičius, Sankauskienè, 2013). The defect analysis of reinforced concrete structures in hydroshemes of Lithuania were presented in scientific literature as follows: slabs for earth dam slope protection (Šadzevičius et al, 2011), service bridges (Šadzevičius, Mikuckis, 2010), retaining walls (Šadzevičius et al, 2009; Šadzevičius et al, 2013).

The technical state of abandoned hydraulic structures in Lithuania has not been evaluated since the status and the owner were not clear in previous investigations. These structures have been included in municipal property balances since 2010. Almost all the necessary legal documents for the design, construction and maintenance of hydraulic structures have been developed and adopted (Technical Construction Regulations STR 2.02.06:2004, STR 2.05.05:2005, STR 1.03.07:2017). There is a lack of proper maintenance of these structures, so technical state of them is decreased and there is a potential probability of failures. There is no decision at the state level what to do with these structures: to repair them, to reconstruct or to demolish and to restore the former natural river beds. From economical point of view - it is more important to preserve the already installed hydraulic structures of reinforced concrete by means of timely repair or reconstruction.

Aim of research: To investigate and to evaluate the technical state of the abandoned hydraulic structures by identifying and assessing the major defects and damage, by forecasting the damage development and the impact on structure safety.

Object of research: The investigated abandoned hydraulic structures are in the territory of Lithuania, the main attention is focused on Klaipėda, Kaunas, Tauragè, Šiauliai, Utena, Panevėžys counties. 17 abandoned hydroschemes in Raseiniai distr. Kaunas county were chosen for a more detailed investigations: Juteikiai, Tauručiai, Verėduvaitė, Paturkšlys, Betygala, Pramedžiava, Girkalnis I, Girkalnis II, Kaulakiai II, Dumšiškiai, Piktaičiai, Gyliai I, Gyliai II, Vejukai, Viduklè, Paviduklè, Vailabai. In this paper, the investigation results of technical state evaluation of 4 typical abandoned hydroschemes from Raseiniai distr. Kaunas county are presented.

\section{METHODS OF RESEARCH}

The following methods were applied for the inspection of concrete and reinforced concrete structures of abandoned hydroschemes and the evaluation of their technical state:

- Visual examination: structures observation on site and the photo fixation of damaged elements.

- Non-destructive method for the determination of strength of concrete.

The technical state of elements in hydroscheme was evaluated using defectiveness points $\left(B_{u},\right)$ in ten points criterion system in accordance with the standing construction regulations STR 1.03.07:2017: 0 point - ideal state, 10 points - critical state.

If any of the main elements of hydroscheme receives the evaluation from 8.1 to 10 defectiveness points, the whole hydroscheme state is evaluated with the same amount of point. In other cases, averages of structures defectiveness points are calculated in order to determine the total hydroscheme defectiveness points. The defects and the causes of deteriorations as well as their magnitude were analyzed according to the project solutions described in regulations (STR 1.03.07:2017).

The visual method enables to evaluate such surface defects of structures as broken corners, edges, deteriorated concrete covering layer, stratified concrete, cracks, bad concrete pouring and steel corrosion. During field investigations smoothness of concrete surfaces, cracks, deflection, character and causes of defects, areas and the depths of cracks, deteriorations, deformations and scour were established.

Simple instruments (tape-measure, tape, levels) were used during the visual examination of a dam, for drainage, reinforced concrete plates for slope protection and their joint inspections - manual and mechanical tools for resurrection. Defects and deteriorations of hydraulic structures were documented using photography methods.

The non-destructive testing of compressive strength was performed in accordance with the European Standard EN 12504-2:2012 "Testing concrete in structures. Part 2. Non-destructive testing. Determination of rebound number" using the calibrated rebound device - the rebound hammer of concrete, Schmidt's hammer, which was calibrated using the standard anvil before and after every examination.

\section{RESEARCH RESULTS}

Summarized data of the number of hydraulic structures in Lithuanian hydroshemes with ponds in 2007 and 2016 are presented in Fig.1. The information about these structures was obtained by analyzing literature sources (Evaluation of technical state of ..., 2007; Reclaimed land and ..., 2017).

According to the results presented in Figure 1, the number of hydraulic structures in Lithuanian hydroshemes with ponds reduced only in Telšiai and Šiauliai counties (period from 2007 - 2016). The biggest number of new hydraulic structures was observed in Vilnius (20 new hydraulic structures) and Klaipėda (12 new hydraulic structures) counties. 


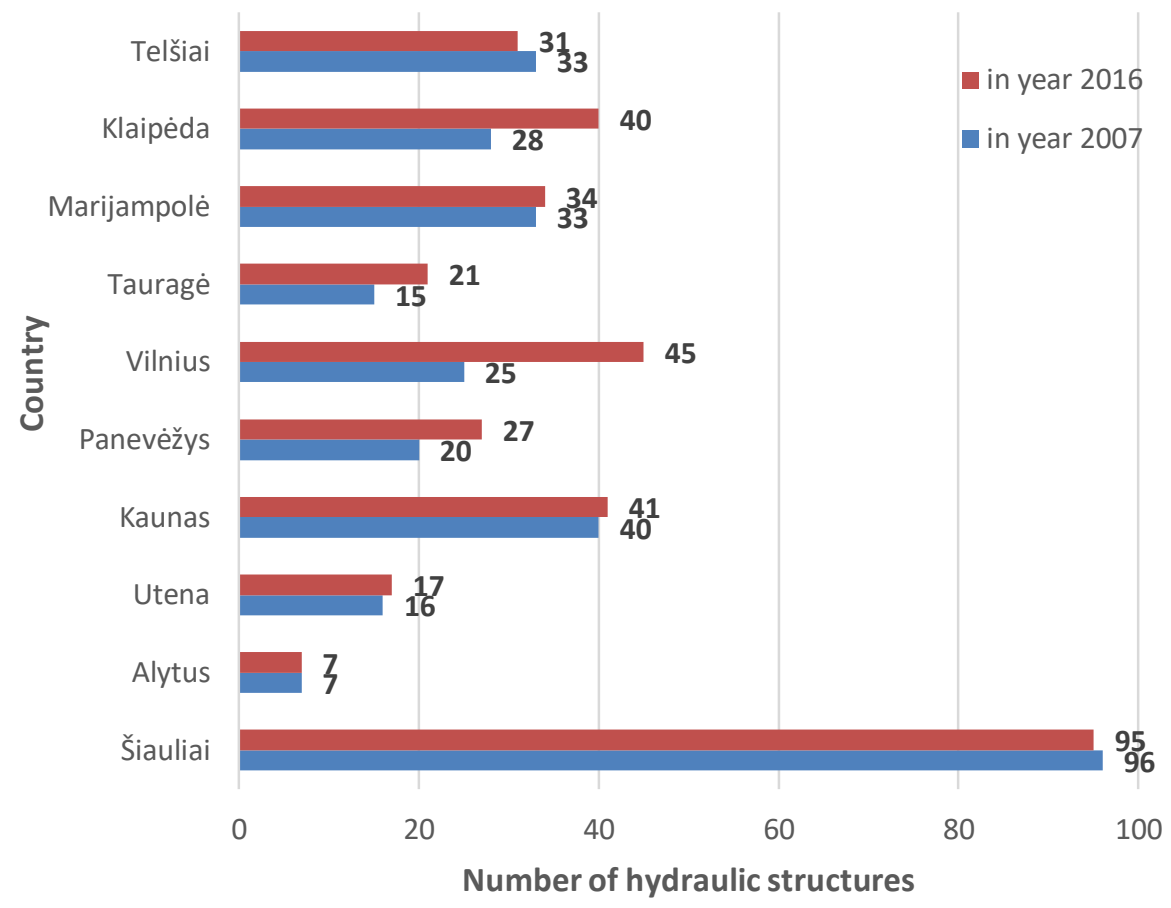

Figure 1. The number of hydraulic structures in Lithuania hydroshemes with ponds in 2007 and 2016

The analysis of scientific literature (Evaluation of technical state of ..., 2007) shows, that the most detailed data about abandoned hydraulic structures in hydroshemes with ponds was presented in 6 counties of Lithuania in 2007. There is a lack of information about 4 counties of Lithuania (Vilnius, Telšiai, Alytus, Marijampolè). According to the results (from 6 counties of Lithuania) presented in Figure 2, the biggest number of abandoned hydraulic structures in Lithuanian hydroshemes with ponds is in Kaunas county. 17 abandoned hydroschemes in Raseiniai distr. Kaunas county were selected for more detailed investigations: Juteikiai, Tauručiai, Verėduvaitė, Paturkšlys, Betygala, Pramedžiava, Girkalnis I, Girkalnis II, Kaulakiai II, Dumšiškiai, Piktaičiai, Gyliai I, Gyliai II, Vejukai, Viduklè, Paviduklè, Vailabai.

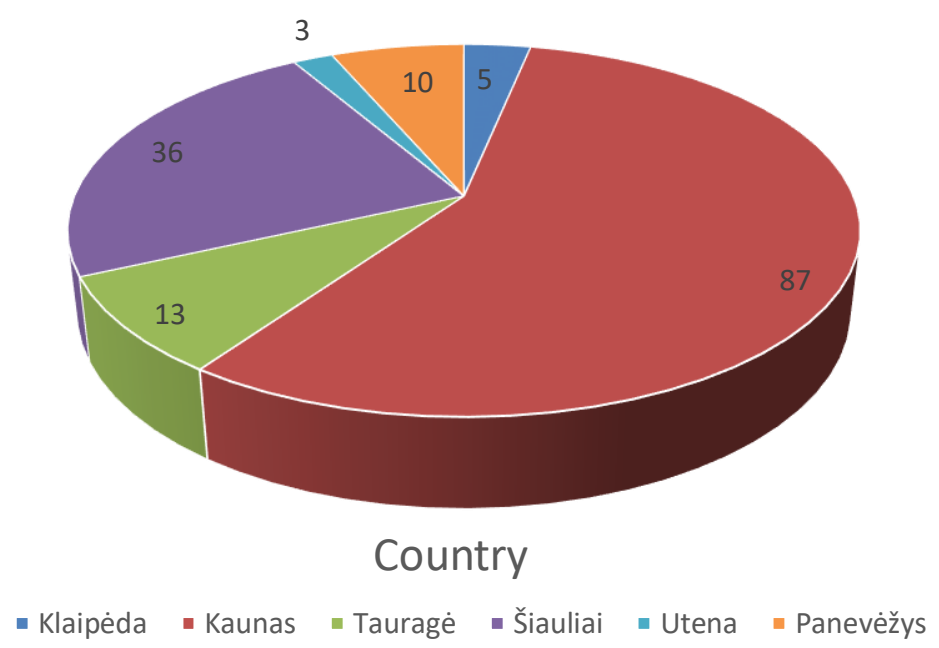

Figure 2. The number of abandoned hydraulic structures in hydroshemes with ponds in 2007 in six Lithuania counties

This paper focuses on the presentation of investigation results of technical state evaluation of 4 abandoned hydroschemes from Raseiniai distr. Kaunas county (Table 1). Due to the noticed significant defects and deteriorations, which reduces greatly the strength and reliability of hydroscheme elements, all 4 hydroschemes are in critical state. 
Table 1. Evaluation of technical state of investigated abandoned hydroschemes in Raseiniai distr. Kaunas county

\begin{tabular}{|c|c|c|c|c|c|}
\hline $\begin{array}{l}\text { Name of } \\
\text { the pond }\end{array}$ & $\begin{array}{l}\text { Construc- } \\
\text { tion date }\end{array}$ & $\begin{array}{l}\text { Most damaged structures, type of damage, } \\
\text { technical state of structures, in points }\end{array}$ & $\begin{array}{c}\text { Place of } \\
\text { measurement }\end{array}$ & $\begin{array}{l}\text { Characte- } \\
\text { ristic } \\
\text { compres- } \\
\text { sion } \\
\text { strength } \\
f_{\text {ck.cub } \mathrm{MPa}}\end{array}$ & $\begin{array}{l}\text { Evaluation of } \\
\text { whole } \\
\text { hydroscheme } \\
\text { technical state, in } \\
\text { points }\end{array}$ \\
\hline \multirow[t]{2}{*}{ Gyliai I } & \multirow[t]{2}{*}{1976} & \multirow{2}{*}{$\begin{array}{l}\text { The shaft culvert is "monk" type, unsupervised, } \\
\text { removed shandors (9.0). The other main } \\
\text { elements of the dam are evaluated in } 8.1-8.5 \\
\text { points. The dam should be repaired } \\
\text { immediately. } \\
\begin{array}{l}\text { Service bridge fallen from support, not } \\
\text { performing its function (10.0) }\end{array}\end{array}$} & - & - & \multirow[t]{2}{*}{9.0} \\
\hline & & & - & - & \\
\hline \multirow[t]{2}{*}{ Gyliai II } & \multirow{2}{*}{1976} & \multirow{2}{*}{$\begin{array}{l}\text { The shaft culvert is "monk" type, unsupervised } \\
\text { ( } 8.5) \text {. Other main elements of the dam are } \\
\text { evaluated in } 8.1-8.5 \text { points, gates evaluated in } \\
10.0 \text { points. The pond is emptied. }\end{array}$} & $\begin{array}{l}\text { Above designed } \\
\text { water level }\end{array}$ & 28.5 & \multirow{2}{*}{10.0} \\
\hline & & & $\begin{array}{l}\text { Under designed } \\
\text { water level }\end{array}$ & 19.5 & \\
\hline \multirow[t]{2}{*}{ Gyliai III } & \multirow{2}{*}{1976} & \multirow{2}{*}{$\begin{array}{l}\text { The shaft culvert is "monk" type, unsupervised } \\
\text { (8.2). Some of the main elements of the dam are } \\
\text { evaluated } 8.1-8.2 \text { points, the dam does not } \\
\text { perform its functions. }\end{array}$} & $\begin{array}{l}\text { Above designed } \\
\text { water level }\end{array}$ & 27.5 & \multirow{2}{*}{8.2} \\
\hline & & & $\begin{array}{l}\text { Under designed } \\
\text { water level }\end{array}$ & 15.0 & \\
\hline \multirow[t]{2}{*}{ Gyliai IV } & \multirow{2}{*}{1976} & \multirow{2}{*}{$\begin{array}{l}\text { The shaft culvert is "monk" type, unsupervised } \\
(9,0) \text {. Some of the main elements of the dam are } \\
\text { evaluated in } 8.1-9.0 \text { points, the dam does not } \\
\text { perform its functions. }\end{array}$} & $\begin{array}{l}\text { Above designed } \\
\text { water level }\end{array}$ & 20.5 & \multirow{2}{*}{9.0} \\
\hline & & & $\begin{array}{l}\text { Under designed } \\
\text { water level }\end{array}$ & 7.5 & \\
\hline
\end{tabular}

According to the results of testing of the concrete compression strength (performed by non-destructive test method), it was established that the characteristic compression strength $f_{\text {ck.cub }}$ of reinforced concrete shaft culvert is bigger in the part above the designed water level by 146 to $273 \%$ in comparison with the part under the designed water level (Table 1). These parts of weak concrete (corrosion of concrete can be seen in more light color of concrete and the deteriorations are under the designed water level) are visible seen in figures 3 and 4.

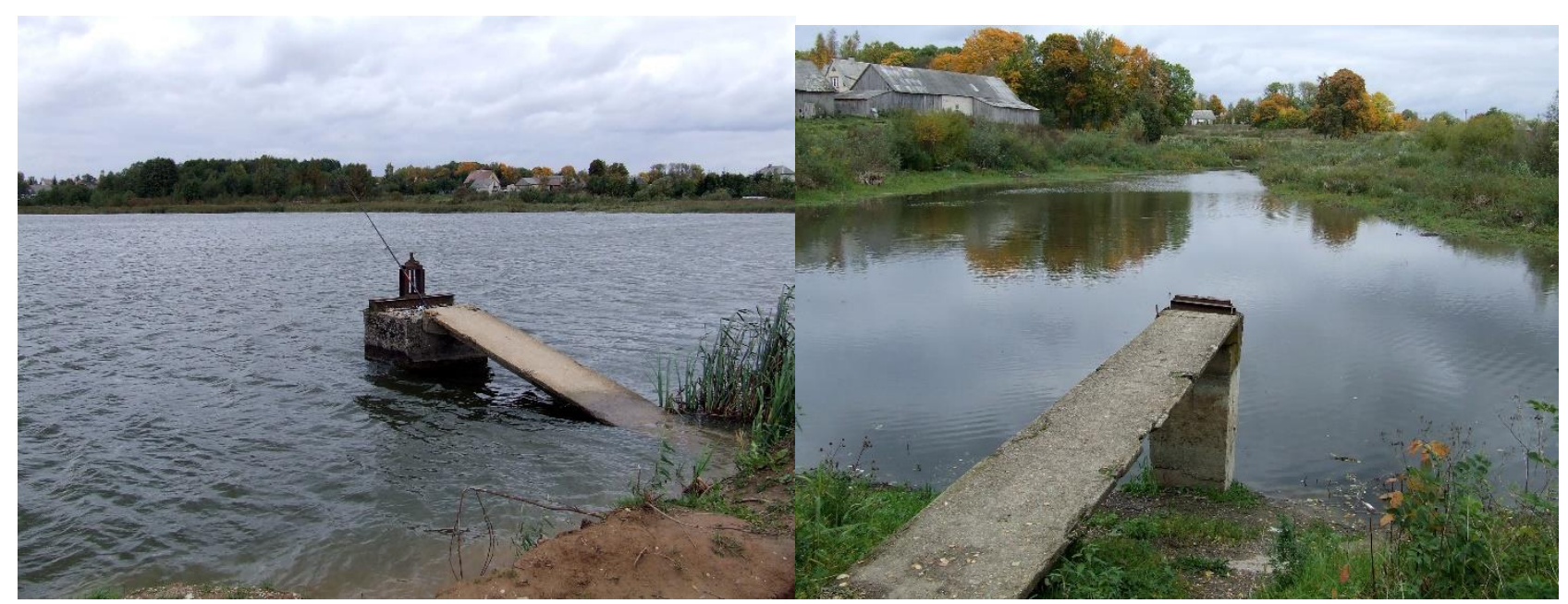

Figure 3. The shaft culverts in Gyliai I and Gyliai II abandoned hydroschemes

The broken corners, edges, the deteriorated concrete covering layer, the stratified concrete, cracks, bad concrete pouring and steel corrosion, the deformations of service bridges and shaft culverts are presented in figures 3 and 4 . The propagation of noticed dangerous defects and deteriorations could lead to the collapse of shaft culverts that are attributed to the category of main structures of a hydroscheme. 


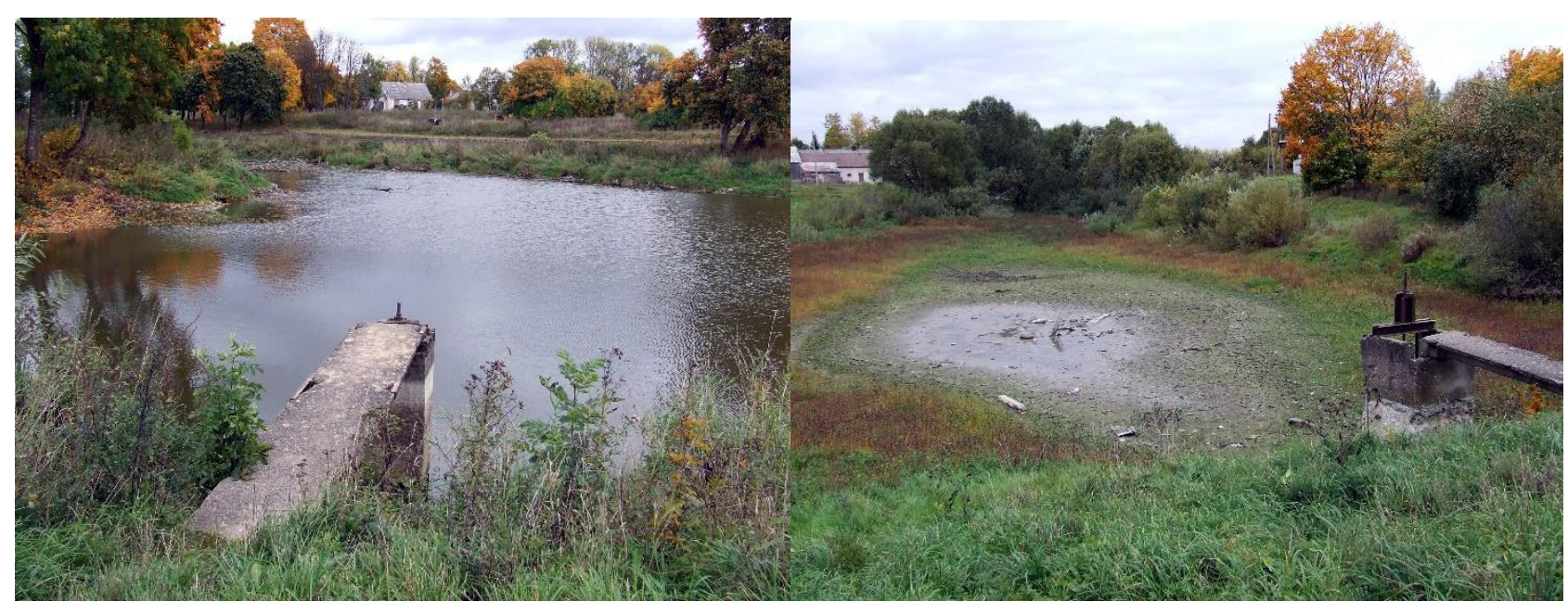

Figure 4. The shaft culverts in Gyliai III and Gyliai IV abandoned hydroschemes

According to the results of technical state investigation of abandoned hydroschemes in Raseiniai distr., the main defects and deteriorations of reinforced concrete structures are: bigger horizontal and vertical cracks; deformations; tilt in shaft; scour; deterioration, delamination, disintegration and cracking of concrete cover layer; collapsing of junctures; corrosion of reinforcement and concrete. Similar results were obtained by lithuanian (Šadzevičius et al, 2009; Šadzevičius, Mikuckis, 2010; Šadzevičius et al, 2011; Šadzevičius, Sankauskienė, 2013; Šadzevičius et al, 2013) and norvegian (Jensen 2001) researchers.

The main processes/reasons that cause deterioration and deformations are the following:

- the environmental impacts (freeze - thaw; ice, wave blows; collapsing impacts; periodical wetting and etc.);

- reinforcement corrosion, alkali aggregate reaction, leaching, erosion, deformation/expansion;

- bad concrete work: low quality of building materials, lack of supervision during hardening of concrete and later;

- in some cases - bad design decisions.

\section{CONCLUSIONS}

1. According to the results of technical state investigation of abandoned hydroschemes in Raseiniai distr., the main defects and deteriorations of reinforced concrete structures are remarkable and dangerous for the whole hydroscheme. Due to the noticed significant defects and deteriorations that greatly reduce the strength and reliability of hydroscheme elements) all 4 hydroschemes are evaluated by 8.2-10.0 points and are in critical state.

2. The shaft culverts in Gyliai I, Gyliai II, Gyliai III abandoned hydroschemes could be reconstructed using bigger diameter corrugated metal pipes. These reconstruction principles and possibilities could be applied in the reconstruction of abandoned hydraulic structures in Lithuania.

3. The pond in Gyliai IV hydrosheme is emptied, shaft culvert and the whole hydrosheme are in critical state and dangerous for the community, the demolition of reinforced concrete structures should be applied in this object.

\section{REFERENCES}

1. Chen, J., Masoud, S., Xuehui, A., 2005. Experimental and numerical study of cracking behavior of openings in concrete dams. Computers and Structures, Vol. 83, No 8-9, pp. 525-535. https://doi.org/10.1016/j.compstruc.2004.11.002Technical Construction Regulation STR 2.05.05:2005. Design of concrete and reinforced concrete structures (in Lithuanian).

2. Catalog of ponds. 1998. Ministry of Environment, Service of hydrographic network. Kaunas. (in Lithuanian)

3. Damulevičius, V.; Rimkus, Z.; Vyčius, J. 2001. Investigation of the technical state of hydraulic structures in Lithuania. Water management engineering, Vol. 15(37), pp. 81-89.

4. EM 1110-2-2002. 1995. Evaluation and Repair of Concrete Structures. Dept. Of the Army U.S. Army Corps of Engineers. Washington.

5. European Standard EN 206:2013+A1:2017. Concrete - Specification, performance, production and conformity.

6. European Standard EN 12504-2:2012. Testing concrete in structures. Part 2: Non-destructive testing. Determination of rebound number.

7. Evaluation of technical state of reclaimed land and structures for land reclamation. Information about municipalized reclaimed land \& land reclamation structures, including hydraulic structures owned by state. 2007. Vilnius, Municipal institute of landscape. 119 p. (in Lithuanian)

8. Jensen, V. 2001. Survey about damage, repair and safety of Norwegian concrete dams. ICOLD European Symposium. Geiranger, Norway, 2527 June, 2001.

9. Lindišas L., Ramonas Č., Vaišvila K. A., Žekevičius, R. 1997. The creation of evaluation methods on the technical state of reinforced concrete hydraulic structures. Kaunas: Akademija. 83 p. (in Lithuanian)

10. Reclaimed land and land reclamation structures for land reclamation (2017-01-01). 2017. Vilnius, Publications of State Land Fund. 60p. (in Lithuanian)

11. Skominas R., Gurskis V., Šadzevičius R., Damulevičius V., Radzevičius A. 2016. Evaluation of cement mortar suitability for repairing concrete in hydraulic structures. KSCE Journal of Civil Engineering, 2017, Vol. 21, Iss. 7, pp. 1-7. https://doi.org/10.1007/s12205-017-1066-z 
12. Šadzevičius R., Damulevičius V., Skominas R. 2013. The technical state of earth dams in Lithuania. Journal of environmental engineering and landscape management. Technika, Vol. 21, No. 3, p. 180-188. ttps://doi.org/10.3846/16486897.2012.662910

13. Šadzevičius R., Sankauskienè T. 2013. Analysis of Technical State Changes of Spillway Concrete Gravity Dams in Municipalities of Marijampole and Kedainiai District. Rural development 2013: the sixth international scientific conference, 28-29 November, 2013, Akademija: Aleksandras Stulginskis University, Vol. 6, b. 3, pp. 470-476.

14. Šadzevičius R. Sankauskienè T., Mikuckis F. 2013. Limit deformations of retaining walls in Lithuanian hydroschemes. Civil Engineering'13: 4th international scientific conference : proceedings. Latvia University of Agriculture. Jelgava., vol. 4, part 1, pp. 336-340.

15. Šadzevičius R., Mikuckis F., Ramukevičius D. 2011. Defect analysis of reinforced concrete slabs for earth dam slope protection. Civil Engineering'11: 3rd international scientific conference, 12-13 May, 2011: proceedings / Latvia University of Agriculture. Jelgava, Vol. 3, p. 44-49.

16. Šadzevičius R., Mikuckis F. 2010. Defects and deteriorations of the reinforced concrete service bridges on the hydroschemes. Water Management Engineering,Vol. 36 (56), pp. 92-99. (in Lithuanian)

17. Šadzevičius R., Patašius A.; Mikuckis,F. 2009. The classification of cracks according their riskiness for structures of reinforced concrete wing walls on stilling basin of hydroschemes. Water Management Engineering, Vol. 35(55), pp. 110-116. (in Lithuanian)

18. Technical Construction Regulation. STR 1.03.07:2017. Order of technical and maintenance supervision of buildings. Order of formation of new real estate cadaster objects (in Lithuanian).

19. Technical Construction Regulation. STR 2.02.06:2004. Hydraulic structures. The basic provisions (in Lithuanian). 